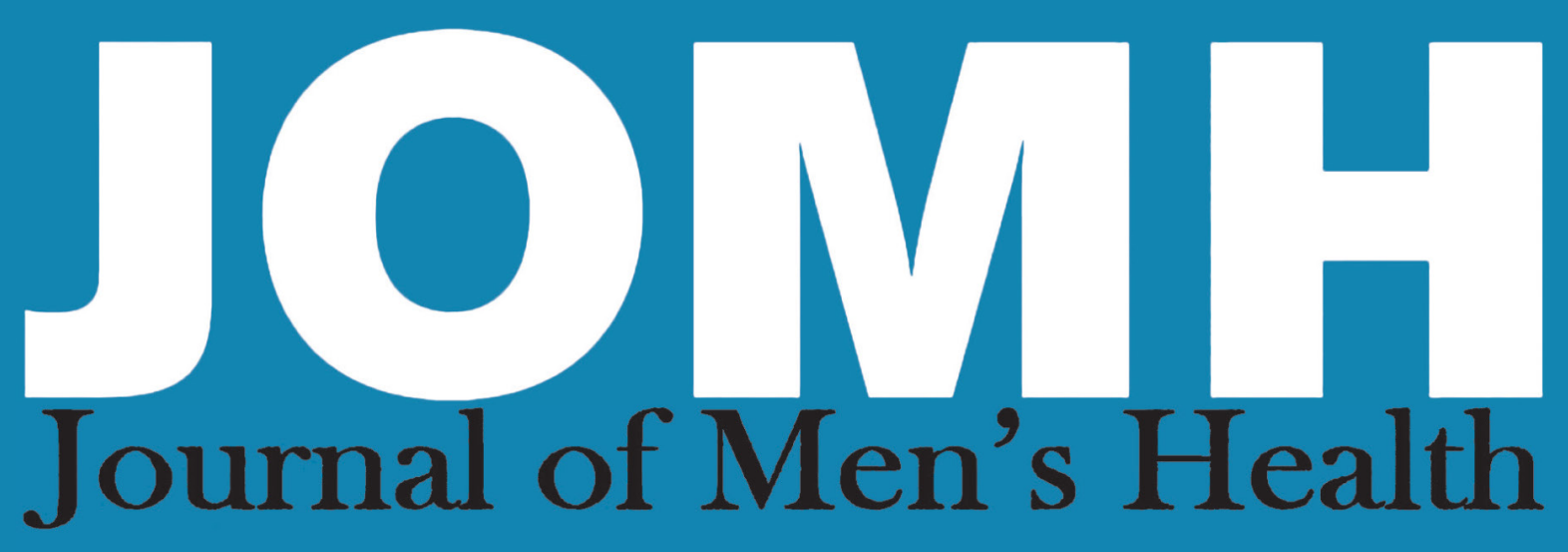

Review

DOI: $10.31083 /$ jomh.v16i4.313

\title{
UNCERTAINTY BASED ON VIRUS REPORTS: WHAT IS THE EFFECT OF SARS-COV-2 ON MALE REPRODUCTION? (COVID-19 AND MALE REPRODUCTION)
}

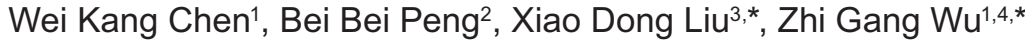 \\ 'Department of Andrology, The First Affiliated Hospital of Wenzhou Medical University, Wenzhou, \\ Zhejiang Province, China \\ ${ }^{2}$ Department of Emergency, The Third Affiliated Hospital of Wenzhou Medical University, Wenzhou, \\ Zhejiang Province, China \\ ${ }^{3}$ School of Public Administration and Health, Wenzhou Medical University, Wenzhou, \\ Zhejiang Province, China \\ ${ }^{4}$ Reproductive Health Research Center, Health Assessment Center of Wenzhou Medical University, \\ Wenzhou, Zhejiang Province, China
}

*Corresponding Authors: Xiao Dong Liu: liuxd2002@126.com and Zhi Gang Wu: andrologywzg@wmu. edu.cn

Submitted: 01 September 2020. Accepted: 13 October 2020. Published: 28 October 2020.

\section{ABSTRACT}

\section{Background and objectives}

Coronavirus disease 2019 (COVID-19) has become a pandemic. Preliminary data reported that severe acute respiratory syndrome coronavirus 2 (SARS-CoV-2) might not be found in the semen of patients in the early stages of COVID-19; however, the virus may be seen in the semen in the late, severe stages. To determine the effects of SARS-CoV-2 infection on the male reproductive system.

\section{Materials and methods}

We reviewed the relationship between previously reported infections with mumps virus (MuV), HIV, Zika virus, hepatitis virus $B$, hepatitis virus $C$, SARS-CoV, and influenza viruses that could possibly damage the male reproductive system, and then investigated whether SARS-CoV-2 infection could cause any damage to the male reproductive system. 


\section{Results}

There were various reports that viruses could impair male reproduction by entering into the testicular cells, inducing inflammation, or both. Regarding SARS-CoV-2, five recent independent studies showed no evidence to suggest that SARS-CoV-2 could be found in the semen and testicular tissues, suggesting that SARS-CoV-2 would not directly damage the blood-testis barrier (BTB) in the early stages of COVID-19 infection. However, a study found that viral RNA was found in 6 out of 38 patients. Three studies found that there were some changes in the sexual hormone levels.

\section{Discussion and conclusion}

There is a lack of substantial evidence to determine how SARS-CoV-2 affects male reproduction at this moment. Understanding of the relationship between SARS-CoV-2 and male infertility requires further research.

Keywords: COVID-19; male reproduction; SARS-CoV-2; virus

\section{INTRODUCTION}

Pneumonia was the primary manifestation of SARS-CoV-2 infection that appeared in Hubei Province, China, in December 2019. Researchers quickly discovered a new coronavirus that caused cause acute respiratory distress syndrome and severe pneumonia. The World Health Organization named it coronavirus 2019 (COVID-19)., ${ }^{1,2}$ Subsequently, COVID-19 caused a pandemic, with patients in 188 countries. To date, the total number of COVID19 patients worldwide has reached an alarming 24,746,587, including 5,917,439 confirmed cases in the United States (Data from https://coronavirus. jhu.edu/map.html, 2020/8/29).

Medical professionals and researchers around the world are diligently working together to fight this pandemic, and a large number of COVID-19-related articles have been published in peer-reviewed journals. We found that COVID-19 was more common in men, and the conditions were mainly mild among those receiving treatment in the general ward. There was also a proportion of patients of reproductive age. ${ }^{1-5}$

In the past, viruses (e.g., mumps virus [MUV], human immunodeficiency virus [HIV], hepatitis virus B [HBV], and others) were shown to affect the reproductive function of male patients, and caused symptoms of testicular pain or abnormal semen quality. In addition, a large group of these men infected by SARS-CoV were of reproductive age. This raises concerns for the possible effect of SARS-CoV-2 on fertility. In the present study, we investigated the possible mechanisms of damage to male reproduction by MuV, HIV, Zika virus (ZIKV), HBV, HCV, and SARS-CoV, specifically focused on the impact of SARS-CoV-2 to attract the attention of medical staff and scientific researchers around the world.

\section{Viruses related to male reproduction}

Studies have found that some viruses can affect male fertility via various mechanisms. However, some viruses are suspected of causing damage to male fertility without compelling evidence, requiring more future research. Below, we have reviewed viruses related to the impairment of male reproduction and reviewed the literature of damage to the reproductive tract by the possible mechanisms. The specific methodology is showed in Table 1.

\section{$M u V$}

$\mathrm{MuV}$ is an enveloped negative-sense RNA virus that belongs to the genus Rubulavirus of the family Paramyxoviridae and can cause human testicular disease. Orchitis is a common complication of mumps in men after puberty, and it occurs in $20-30 \%$ of mumps cases. ${ }^{6} \mathrm{MuV}$ infection in some 
TABLE 1 The Specific Methodology of Literature Related to MuV, HIV, Zika Virus, Hepatitis Virus B, Hepatitis Virus C, and SARS-CoV.

\begin{tabular}{|l|l|}
\hline Animal experiment & $\begin{array}{l}(9),(12-13),(40-41),(43-44), \\
(46),(63),(73-76)\end{array}$ \\
\hline $\begin{array}{l}\text { Human cell or tissue } \\
\text { experiment }\end{array}$ & $\begin{array}{l}(14),(15),(20-25),(29-30), \\
(33-34),(38-39),(42),(45), \\
(47),(50),(59-60),(64-65), \\
(67-68),(70),(72)\end{array}$ \\
\hline $\begin{array}{l}\text { Human examination } \\
\text { or observation }\end{array}$ & $\begin{array}{l}(7),(10-11),(18),(26),(35-36), \\
(49),(51-58),(61),(71)\end{array}$ \\
\hline
\end{tabular}

patients may transiently reduce the number of sperm and change the sperm morphology. Bilateral mumps orchitis accounts for $18.2 \%$ of cases (2/11 patients) and usually leads to infertility associated with testicular atrophy.?

The mechanism of how MuV infection impairs testis was elaborated in some animal experiments. $\mathrm{MuV}$ induces innate immune responses in mouse Sertoli cells via activation of toll-like receptor 2 (TLR2), which induces the expression of proinflammatory cytokines TNF- $\alpha$ and IL- 6 and chemokines MCP-1 and CXCL10. ${ }^{8}$ Under inflammatory conditions, TNF- $\alpha$ can be upregulated, and it can inhibit the production of testosterone by impairing the Leydig cells. ${ }^{9-11} \mathrm{TNF}-\alpha$ produced by Sertoli cells after MuV infection induced apoptosis in male germ cells. ${ }^{12}$ Another study confirmed the mechanism of MuV-mediated disruption of the blood-testis barrier (BTB) and the impairment of spermatogenesis through the activation of TLR2 signaling. ${ }^{13}$ Other studies demonstrated the harmful effects on the production of testosterone and spermatogenesis caused by infection with the $\mathrm{MuV}$, which targets Leydig cells as a site of replication within the testes. ${ }^{14,15}$ Nevertheless, the lack of human samples limits the opportunity to study the pathogenesis of mumps in patients. Therefore, information can only be obtained through animal models.

\section{HIV}

Acquired immune deficiency syndrome (AIDS) is a potentially deadly infectious disease caused by infection with HIV. HIV is a virus that can attack the body's immune system, especially CD $4{ }^{+} \mathrm{T}$ lymphocytes, as the main target of attack, ultimately severely compromising the immune function. HIVinfected patients are susceptible to various diseases with high case fatality rates ${ }^{16,17}$ while there are some people living with HIV (PLW-HIV) (there is a lack of reports on reproduction in the literature, so the corresponding discussion will not be carried out below). HIV is classified into two types, HIV-1 and HIV-2. HIV-1 is the main cause of most HIV infections while HIV-2 is rare; there are only a few relevant studies. HIV-1 can be detected in the semen. ${ }^{18}$ A number of studies reported that the virus damages male infertility in a number ways, as described below. Several studies mentioned that HIV-1-positive men suffer from testicular injury and endocrine disorders, which manifest as chronic orchitis or progressive hypogonadism. ${ }^{19,20}$ Surprisingly, testes mostly showed atrophy in AIDS, probably due to germ cell loss, interstitial fibrosis, or lymphocytic infiltrate, ${ }^{21}$ and HIV-1 DNA was detected in male germ cells..$^{22,23}$ In some studies, testicular changes in patients who died from AIDS were divided into five categories (Figure 1). ${ }^{24,25}$ An article reported that serum testosterone levels in AIDS patients were low, while LH and FSH levels were high, suggesting that testosterone synthesis was impaired. ${ }^{26} \mathrm{HIV}-1$ damages male reproduction by killing various types of testis cells. The mechanism that causes male infertility may include damage to germ cells and Sertoli cells, causing widespread inflammation, or Leydig cells causing testosterone abnormalities. Nevertheless, further mechanisms remain to be clarified.

\section{Human papillomavirus}

Human papillomavirus (HPV) infection is one of the most common sexually transmitted diseases (STD) worldwide. It often infects reproductive-age men and women. There is controversy regarding 


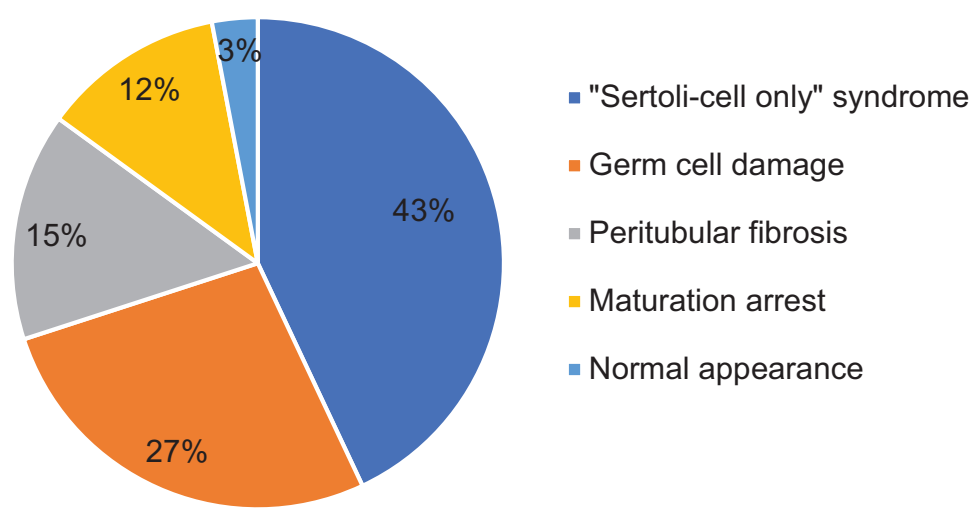

FIGURE 1 The categories of testicular changes in patients who died from acquired immune deficiency syndrome.

whether HPV can cause infertility in infected patients. Some studies suggested that the virus damaged the sperm quality and caused poor pregnancy outcomes. ${ }^{27-31}$ Other scholars hold different views regarding the detection methods of HPV in the semen and the effect of HPV infection on the semen parameters. ${ }^{32-35}$ The four possible biological mechanisms by which HPV infection causes male infertility are as follows. ${ }^{32}$ HPV could combine with the sperm head tightly, leading to a decrease in sperm motility; ${ }^{33,36}$ HPV may jeopardize the integrity of sperm DNA and lead to apoptosis of spermatozoa; HPV infection may induce the generation of anti-sperm antibodies, resulting in interference with sperm motility and sperm-oocyte binding; finally, HPV could be transferred into blastocysts, causing adverse pregnancy outcomes. All these mechanisms require further research and confirmation.

\section{ZIKV}

ZIKV is a positive-stranded RNA virus belonging to the Flavivirus family. It can be sexually transmitted from man to woman, and it is frequently detected in the semen of infected men. ${ }^{37,38}$ ZIKV RNA lasts longer, and in most cases, its levels in the semen are higher than those in blood. ${ }^{39}$ Govero et al. showed that ZIKV caused epididymitis, reducing sperm motility. ${ }^{40}$ Uraki et al. found that Leydig cells served as targets and reservoir cell types for ZIKV within the testes and may be impaired by ZIKA virus, thereby reducing the serum testosterone levels. ${ }^{41}$

Other researchers found that Leydig cells were highly sensitive to Zika virus infection in human and mouse models. ${ }^{42,43}$ Other studies found that ZIKV caused testicular atrophy, infected Sertoli cells, and modulated the integrity of the BTB in an in vitro model by inducing inflammation. ${ }^{44-47}$ Nevertheless, there is no compelling evidence of ZIKV-reduced fertility in humans, limited to two case reports of hematospermia. ${ }^{48,49}$

\section{Hepatitis viruses}

Hepatitis viruses are divided into five types; they are mostly RNA viruses, except for HBV, which is a DNA virus. Both HBV and HCV have been found in the semen and may be sexually transmitted, while HCV loads are lower than those of HBV. ${ }^{50}$ Studies have found that both viruses injure the semen parameters, thereby reducing male fertility, including sperm counts, motility, and morphology $\mathrm{y}^{51-57}$ (Table 2). HBV and HCV were suspected of damaging the sperm by causing increases in reactive oxygen species (ROS) and subsequently inducing apoptosis, thereby causing abnormal semen 
TABLE 2 Review of the Literature on the Influence of Hepatitis Virus B and Hepatitis Virus C Semen Infection on Sperm Parameters.

\begin{tabular}{|c|c|c|c|c|}
\hline $\begin{array}{l}\text { Type of Hepatitis } \\
\text { viruses }\end{array}$ & References & Sperm count & Motility & Normal morphology \\
\hline \multirow[t]{3}{*}{ Hepatitis virus B } & Vicari et al., $2006^{52}$ & $\downarrow$ & $\downarrow$ & $\downarrow$ \\
\hline & Lorusso et al., $2010^{51}$ & $\downarrow$ & $\downarrow$ & $\downarrow$ \\
\hline & Zhou et al., 201153 & $\downarrow$ & $\downarrow$ & \\
\hline \multirow[t]{5}{*}{ Hepatitis virus $\mathrm{C}$} & Durazzo et al., $2006^{54}$ & N.D. & $\downarrow$ & $\downarrow$ \\
\hline & Lorusso et al., $2010^{51}$ & $\downarrow$ & $\downarrow$ & $\downarrow$ \\
\hline & Safarinejad et al., $2010^{57}$ & $\downarrow$ & $\downarrow$ & $\downarrow$ \\
\hline & Hofny et al., $2011^{55}$ & $\downarrow$ & $\downarrow$ & $\downarrow$ \\
\hline & La Vignera et al., $2012^{56}$ & $\downarrow$ & $\downarrow$ & $\downarrow$ \\
\hline
\end{tabular}

N.D.: No difference.

parameters. ${ }^{58-61}$ Other studies reported hormone abnormalities, including lower total serum testosterone levels, meaning that the Leydig cells may be damaged. ${ }^{55,57}$

\section{SARS-CoV}

The global outbreak of severe acute respiratory syndrome (SARS) in 2003 infected more than 8000 patients, and 774 of them died, mostly in China. ${ }^{62}$ Studies confirmed that SARS-associated coronavirus (SARS-CoV) was the causative agent of SARS. ${ }^{63-68}$ In the follow-up research, researchers found that the angiotensin-converting enzyme 2 (ACE2) is the functional receptor for SARS-CoV, which is present in the testis. However, no SARS$\mathrm{CoV}$ RNA has been detected in the testis, ${ }^{69,70}$ suggesting that SARS-CoV might not damage the testis by entering these cells directly. SARSinfected testes demonstrated extensive germ cell destruction, with few or no spermatozoa in the seminiferous epithelium or the lumen, caused by probable leukocyte infiltration. Immunohistochemistry demonstrated abundant IgG precipitation in the seminiferous epithelium of SARS testes, suggesting possible immune responses as the cause for the damage. ${ }^{70}$ The question as to whether SARS-CoV impairs male infertility requires further validation.

\section{Influenza}

Influenza is a respiratory virus that causes disease, primarily manifesting as respiratory symptoms. Various viruses have been reported in the literature, and some scholars detected the impact of flu on sperm quality. As a febrile illness, flu may affect the semen quality because of the impact on the semen parameters and sperm DNA integrity caused by fever. ${ }^{71}$ Evenson et al. studied the characteristics of human sperm chromatin structure after influenza and high fever and found that influenza may alter sperm chromatin structure. ${ }^{72}$ Some studies of animal models found that influenza damaged the sperm quality, leading to infertility. ${ }^{73-76}$

\section{COVID-19}

With the global pandemic of COVID-19, the general symptoms of the disease are gradually being known. Patients with COVID-19 mainly present with cough, fever, and dyspnea, as well as abnormal findings on the chest $\mathrm{CT}^{1-3}$ Some patients presented with gastrointestinal symptoms or blood system abnormalities, with or without cardiac and arrhythmic complications. ${ }^{77,78}$ In addition to these patients with obvious symptoms, there are many asymptomatically infected patients with abnormal imaging findings, worthy of our attention. ${ }^{79}$ 
As studies continue to report more patients who present asymptomatically or atypically, Kim et al. reported the first case with the initial symptom of abdominal and testicular pain resulting from SARS-CoV-2 infection. ${ }^{80}$ Pan et al. reported testicular and scrotal pain in $17.9 \%$ of SARS-CoV-2positive patients in their recent study. ${ }^{81}$ Holtmann et al. found that the semen parameters of some SARS-CoV-2-infected patients were impaired ${ }^{82}$ The levels of serum luteinizing hormone (LH) in men with COVID-19 were significantly increased; by contrast, testosterone $(\mathrm{T}) / \mathrm{LH}$ and the ratio of follicle-stimulating hormone (FSH) to $\mathrm{LH}$ was significantly reduced in comparison to age-matched healthy men. ${ }^{83}$ Some studies returned results consistent with these sexual hormone changes. ${ }^{84,85}$ These findings raised our concerns about whether SARS-CoV-2 could affect the reproductive function of male patients, just as other viruses that have been demonstrated to affect male fertility. The relationship between SARS-CoV-2 and male fertility deserves our close attention.

After studying the confirmed or suspected mechanism of various viruses on male reproduction, we divided them into two types:

I. Direct viral injury: Viruses impair male reproduction by entering testicular cells, affecting the sperm integrity of DNA, or transferring into blastocysts to reduce the secondary inflammation, leading to impaired spermatogenesis and poor semen parameters (e.g., HIV, HPV, ZIKV, hepatitis virus...).

II. Indirect viral injury: Viruses are unable to enter cells generally, but can damage testicular cells and sperm by inflammation (MuV, SARS, Influenza...).

We can also roughly divide the methods of viral injury to the initially damaged cells, including Leydig cells, Sertoli cells, germ cells, and sperm; however, SARS-CoV-2 usually impairs male fertility by various methods (both I and II types).
SARS-Cov-2 has a $79 \%$ similarity to SARSCov-1 based on genomic sequencing. Thus, it is not surprising that angiotensin-converting enzyme 2 (ACE2), previously known as the receptor for SARS-CoV, has been confirmed as an essential receptor for SARS-CoV-2 to enter cells. ${ }^{86-89}$ High expression levels of ACE2 in testicular cells (i.e., germ cells, Sertoli cells, and Leydig cells) have been found, especially in this Leydig cells, and this was alarming to researchers.

ACE2 is a homolog of carboxypeptidase. It is the active peptide of the renin-angiotensin system (RAS). ACE2 is a dominant-negative regulator of RAS, which can balance the multiple functions of ACE. Angiotensin-converting enzyme (ACE) is a crucial protease that cleaves angiotensin I to produce angiotensin II. Angiotensin II is a potent vasoconstrictor and stimulant of aldosterone release; it can also enhance inflammation, oxidative stress, and increase coagulation in some experimental and clinical models. ${ }^{90-93}$ However, ACE2 can reduce the adverse effects of angiotensin II by degrading angiotensin II and generating angiotensin,,${ }^{1-7}$ which is the opposite result of angiotensin II. ${ }^{94}$

ACE2 is downregulated by entering into cells that have bound SARS-CoV-2. ${ }^{95-97}$ As a result, the degradation of angiotensin II is impaired, and the product of angiotensin ${ }^{1-7}$ disappears, which may cause subsequent effects induced by angiotensin II (i.e., enhanced inflammation, enhanced oxidative stress, and increased coagulation).

It is unclear as to whether SARS-CoV-2 damages male fertility by using the ACE2 receptor through testicular cells with subsequent cell apoptosis and inflammatory reactions, and whether SARS-CoV-2 could be sexually transmitted. Therefore, it is critical to examine the SARSCoV-2 RNA in the semen samples collected from patients at all stages of COVID-19 infection and obtain testicular samples from autopsy. There are five studies showing no detection of SARSCoV-2 RNA in the semen samples, ${ }^{81,82,98-100}$ while Li et al. ${ }^{101}$ found that there was virus RNA in 6 out 
of the 38 patients (four patients in the acute stage of infection and two patients who had recovered). Pan et al. tested ejaculated semen samples from 34 adult male patients after a median of 31 days from COVID-19 diagnosis, but SARS-CoV-2 was not detected ${ }^{81}$ Holtmann et al. studied 18 semen samples from recovered men and two semen samples from patients with active COVID-19 infection; no RNA was detected using reverse-transcription polymerase chain reaction (RT-PCR). ${ }^{82}$ Song et al. did not detect SARS-CoV-2 RNA in the semen samples of 12 recovered patients and testicular samples from one patient who died of COVID19 during the acute phase. ${ }^{98}$ Paoli et al. found no SARS-CoV-2 RNA in the semen and urine samples. ${ }^{99}$ Ning et al. also did not find SARSCoV-2 RNA in the semen samples of 17 patients with fertility needs. ${ }^{100}$ We cannot conclude as to whether SARS-CoV-2 is sexually transmitted or not. However, current studies have many limitations. First, recent reports providing evidence of SARS-CoV-2 in the semen or testis were too small and immature, and therefore we cannot rule out the existence of SARS-CoV-2 in the semen or testis cells of other infected patients. Second, the absence of virus RNA in the semen analysis does not mean that SARS-CoV-2 cannot invade and damage testicular cells directly. The production of the sperm often takes time to complete spermatogenesis. Furthermore, Sertoli cells and Leydig cells generally do not appear in the semen. Third, there have been few severely infected patients, but viral loads may be too low to be detected. Fourth, patients did not undergo multiple semen tests, and this may increase the possibility of false negatives.

In addition to directly entering the cell, viruses like $\mathrm{HIV}, \mathrm{MuV}, \mathrm{HBV}$, and SARS-CoV can also cause damage to the testicular cells by inducing inflammation and autoimmune reactions. The BTB, which is formed by adjacent Sertoli cells near the basal membrane of the seminiferous tubules, plays a critical role in maintaining the microenvironment essential for the function of the testes. ${ }^{102}$ The BTB is created by several junctions between Sertoli cells, including tight junctions, adhesion junctions, and other junction complexes. ${ }^{103}$ Some viruses cause the active receptor to induce the expression of pro-inflammatory cytokines and chemokines. Following upregulation of pro-inflammatory cytokines and chemokines, the BTB is destroyed and then the leukocytes infiltrate. More importantly, these testicular cells and their related products, inflammatory cytokines, may activate the autoimmune response and autoantibody development, leading to impaired testicular cells, resulting in reduced testosterone production and spermatogenesis disorders. SARS-CoV-2 might possibly trigger a secondary autoimmune response and cause viral orchitis by these mechanisms. In these patients, leukocytes, lymphocytes, macrophages, or IgG might be found in testicular tissues. Nevertheless, there remains a lack of research on this subject.

Therefore, studies provide only the "tip of the iceberg" regarding the potential impacts of SARS$\mathrm{CoV}-2$ on male reproduction. The research suggested that SARS-CoV-2 could both enter the testis and destroy the BTB, potentially causing damage to testicular function and male fertility, and possibly resulting in sexual transmission.

\section{FUTURE RESEARCH DIRECTIONS}

As the pandemic of SARS-CoV-2 rages worldwide, more studies are needed to understand its impact on male fertility.

First, a more significant series of semen samples from patients from all stages of COVID-19 should be collected and there should be an extended duration of semen collection. If possible, tissues from the testis of patients should be collected for testing.

Second, both primary testicular cell damage and subsequent spermatogenesis requires time; therefore, we need long-term monitoring and follow-up of the semen status and sex hormone levels in COVID-19 patients to determine how SARS-CoV-2 affects male fertility. If there are abnormalities, 
intervention should be made in advance to preserve fertility.

Third, due to the ethical limits of human research, more animal models of COVID-19 are needed to determine meaningful outcomes, including studying the possibility of sexual transmission.

\section{CONCLUSIONS}

Many viruses cause direct or indirect impact and damage to male reproduction. With the pandemic of SARS-CoV-2, the issue of whether COVID-19 damages male reproduction needs to be further evaluated with greater attention. Although limited evidence might complicate the process of determining whether there is SARS-CoV-2 in the semen and the testicular tissues of COVID-19 patients, the impact of how SARS-CoV-2 affects the testicular cells, seminal fluid, and testicular pain at all stages of the infection needs to be further investigated. Notably, the possibilities of SARS-CoV-2 as a STD should be carefully studied.

\section{CONFLICTS OF INTEREST}

All authors have completed the ICMJE uniform disclosure form. The authors have no conflicts of interest to declare.

\section{REFERENCES}

1. Chen N, Zhou M, Dong X, et al. Epidemiological and clinical characteristics of 99 cases of 2019 novel coronavirus pneumonia in Wuhan, China: A descriptive study. Lancet 2020;395:507-13. https:// doi.org/10.1016/S0140-6736(20)30211-7

2. Huang C, Wang Y, Li X, et al. Clinical features of patients infected with 2019 novel coronavirus in Wuhan, China. Lancet 2020;395:497-506. https:// doi.org/10.1016/S0140-6736(20)30183-5

3. Garg S, Kim L, Whitaker M, et al. Hospitalization rates and characteristics of patients hospitalized with laboratory-confirmed coronavirus disease 2019 - COVID-NET, 14 states, March 1-30, 2020.
MMWR Morb Mortal Wkly Rep 2020;69:458-64. https://doi.org/10.15585/mmwr.mm6915e3

4. Goyal P, Choi JJ, Pinheiro LC, et al. Clinical characteristics of Covid-19 in New York City. N Engl J Med 2020; 382: 2372-2374.. https://doi. org/10.1056/NEJMc2010419

5. Zheng $\mathrm{Y}, \mathrm{Xu} \mathrm{H}$, Yang M, et al. Epidemiological characteristics and clinical features of 32 critical and 67 noncritical cases of COVID-19 in Chengdu. J Clin Virol 2020;127:104366. https:// doi.org/10.1016/j.jcv.2020.104366

6. Masarani M, Wazait H, Dinneen M. Mumps orchitis. J R Soc Med 2006;99:573-5. https://doi. org/10.1177/014107680609901116

7. Casella R, Leibundgut B, Lehmann K, Gasser TC. Mumps orchitis: Report of a mini-epidemic. J Urol 1997;158:2158-61. https://doi.org/10.1016/ S0022-5347(01)68186-2

8. Liu W, Han R, Wu H, Han D. Viral threat to male fertility. Andrologia 2018;50:e13140. https://doi. org/10.1111/and.13140

9. Xiong Y, Hales DB. The role of tumor necrosis factor-alpha in the regulation of mouse Leydig cell steroidogenesis. Endocrinology 1993;132:2438-44. https://doi.org/10.1210/endo.132.6.8504748

10. Tsigos C, Papanicolaou DA, Kyrou I, Raptis SA, Chrousos GP. Dose-dependent effects of recombinant human interleukin- 6 on the pituitary-testicular axis. J Interferon Cytokine Res 1999;19:1271-6. https://doi.org/10.1089/107999099312948

11. Adamopoulos DA, Lawrence DM, Vassilopoulos P, Contoyiannis PA, Swyer GI. Pituitary-testicular interrelationships in mumps orchitis and other viral infections. Br Med J 1978;1:1177-80. https:// doi.org/10.1136/bmj.1.6121.1177

12. Jiang Q, Wang F, Shi L, et al. C-X-C motif chemokine ligand 10 produced by mouse Sertoli cells in response to mumps virus infection induces male germ cell apoptosis. Cell Death Dis 2017;8:e3146. https://doi.org/10.1038/cddis.2017.560

13. Wu H, Jiang $\mathrm{X}$, Gao $\mathrm{Y}$, et al. Mumps virus infection disrupts blood-testis barrier through the induction of TNF- $\alpha$ in Sertoli cells. FASEB J 2019;33:12528 40. https://doi.org/10.1096/fj.201901089R

14. Le Tortorec A, Denis H, Satie AP, et al. Antiviral responses of human Leydig cells to mumps virus 
infection or poly I:C stimulation. Hum Reprod 2008;23:2095-103.https://doi.org/10.1093/humrep/ den 207

15. Le Goffic R, Mouchel T, Ruffault A, Patard JJ, Jégou B, Samson M. Mumps virus decreases testosterone production and gamma interferoninduced protein 10 secretion by human Leydig cells. J Virol 2003;77:3297-300. https://doi. org/10.1128/JVI.77.5.3297-3300.2003

16. Reif S, Pence BW, Hall I, Hu X, Whetten K, Wilson E. HIV diagnoses, prevalence and outcomes in nine southern states. J Community Health 2015;40:642-51. https://doi.org/10.1007/ s10900-014-9979-7

17. Hanna DB, Selik RM, Tang T, Gange SJ. Disparities among U.S. states in HIV-related mortality in persons with HIV infection, 2001-2007. AIDS 2012;26:95-103. https://doi.org/10.1097/ QAD.0b013e32834def87

18. Gupta P, Leroux C, Patterson BK, et al. Human immunodeficiency virus type 1 shedding pattern in semen correlates with the compartmentalization of viral Quasi species between blood and semen. J Infect Dis 2000;182:79-87. https://doi. org/10.1086/315644

19. Poretsky L, Can S, Zumoff B. Testicular dysfunction in human immunodeficiency virus-infected men. Metab Clin Exp. 1995;44:946-53. https://doi. org/10.1016/0026-0495(95)90250-3

20. Pudney J, Anderson D. Orchitis and human immunodeficiency virus type 1 infected cells in reproductive tissues from men with the acquired immune deficiency syndrome. Am J Pathol. 1991;139: 149-60.

21. Rogers C, Klatt EC. Pathology of the testis in acquired immunodeficiency syndrome. Histopathology 1988;12:659-65. https://doi. org/10.1111/j.1365-2559.1988.tb01990.x

22. Muciaccia B, Filippini A, Ziparo E, Colelli F, Baroni CD, Stefanini M. Testicular germ cells of HIV-seropositive asymptomatic men are infected by the virus. J Reprod Immunol 1998;41:81-93. https://doi.org/10.1016/S0165-0378(98)00050-3

23. Nuovo GJ, Becker J, Simsir A, Margiotta M, Khalife G, Shevchuk M. HIV-1 nucleic acids localize to the spermatogonia and their progeny. A study by polymerase chain reaction in situ hybridization. Am J Pathol 1994;144:1142-8.

24. De Paepe ME, Waxman M. Testicular atrophy in AIDS: A study of 57 autopsy cases. Hum Pathol 1989;20:210-14. https://doi.org/10.1016/ 0046-8177(89)90125-1

25. Kossakowska AE, Eyton-Jones S, Urbanski SJ. Immunoglobulin and T-cell receptor gene rearrangements in lesions of mucosa-associated lymphoid tissue. Diagn Mol Pathol 1993;2:233-40. https://doi.org/10.1097/00019606-19931200000002

26. Croxson TS, Chapman WE, Miller LK, Levit CD, Senie R, Zumoff B. Changes in the hypothalamicpituitary-gonadal axis in human immunodeficiency virus-infected homosexual men. J Clin Endocrinol Metab 1989;68:317-21. https://doi. org/10.1210/jcem-68-2-317

27. Gimenes F, Souza RP, Bento JC, et al. Male infertility: A public health issue caused by sexually transmitted pathogens. Nat Rev Urol 2014;11: 672-87. https://doi.org/10.1038/nrurol.2014.285

28. Gizzo S, Ferrari B, Noventa M, et al. Male and couple fertility impairment due to HPV-DNA sperm infection: Update on molecular mechanism and clinical impact-systematic review. Biomed Res Int 2014;2014:230-263. https://doi. org $/ 10.1155 / 2014 / 230263$

29. Kaspersen MD, Larsen PB, Ingerslev HJ, et al. Identification of multiple HPV types on spermatozoa from human sperm donors. PLoS One 2011; 6: e18095. https://doi.org/10.1371/journal. pone. 0018095

30. Perez-Andino J, Buck CB, Ribbeck K. Adsorption of human papillomavirus 16 to live human sperm. PLoS One 2009;4(6):e5847. https://doi.org/10.1371/ journal.pone. 0005847

31. Jeršovienė V, Gudlevičienė Ž, Rimienè J, Butkauskas D. Human papillomavirus and infertility. Medicina 2019;55:377. https://doi.org/10.3390/ medicina55070377

32. Lyu Z, Feng X, Li N, et al. Human papillomavirus in semen and the risk for male infertility: A systematic review and meta-analysis. BMC Infect Dis 2017;17:714. https://doi.org/10.1186/ s12879-017-2812-Z 
33. Foresta C, Patassini C, Bertoldo A, et al. Mechanism of human papillomavirus binding to human spermatozoa and fertilizing ability of infected spermatozoa. PLoS One 2011;6:e15036. https://doi.org/10.1371/journal.pone.0015036

34. Schillaci R, Capra G, Bellavia C, et al. Detection of oncogenic human papillomavirus genotypes on spermatozoa from male partners of infertile couples. Fertil Steril 2013;100:1236-40. https://doi. org/10.1016/j.fertnstert.2013.06.042

35. Zhou L, Pan F, Chen XF, An G, Li SH. Effects of human papilloma virus infection in the male reproductive tract on fertility and embryonic development and its prevention. Chin J Reprod Contracep 2019;39:1030-4.

36. Yang Y, Jia CW, Ma YM, Zhou LY, Wang SY. Correlation between HPV sperm infection and male infertility. Asian J Androl 2013;15:529-32. https://oi.org/10.1038/aja.2013.36

37. Kurscheidt FA, Mesquita CSS, Damke GMZF, Damke E, Carvalho ARBA, Suehiro TT. Persistence and clinical relevance of Zika virus in the male genital tract. Nat Rev Urol 2019;16:21130. https://doi.org/10.1038/s41585-019-0149-7

38. Mead PS, Duggal NK, Hook SA, Delorey M, Fischer M, Olzenak McGuire D. Zika virus shedding in semen of symptomatic infected men. $\mathrm{N}$ Engl J Med 2018;378:1377-85. https://doi. org/10.1056/NEJMoa1711038

39. Mansuy JM, Suberbielle E, Chapuy-Regaud S, et al. Zika virus in semen and spermatozoa. Lancet Infect Dis 2016;16:1106-7. https://doi.org/10.1016/ S1473-3099(16)30336-X

40. Govero J, Esakky P, Scheaffer SM, et al. Zika virus infection damages the testes in mice. Nature 2016;540:438-42. https://doi.org/10.1038/ nature20556

41. Uraki R, Hwang J, Jurado KA, et al. Zika virus causes testicular atrophy. Sci Adv 2017;3:e1602899. https://doi.org/10.1126/sciadv.1602899

42. Kumar A, Jovel J, Lopez-Orozco J, et al. Human Sertoli cells support high levels of Zika virus replication and persistence. Sci Rep 2018;8:5477. https://doi.org/10.1038/s41598-018-23899-x

43. Sheng ZY, Gao N, Wang ZY, et al. Sertoli cells are susceptible to ZIKV infection in mouse testis.
Front Cell Infect Microbiol 2017;7:272. https://doi. org/10.3389/fcimb.2017.00272

44. Ma W, Li S, Ma S, et al. Zika virus causes testis damage and leads to male infertility in mice. Cell 2017;168:542. https://doi.org/10.1016/j.cell. 2017.01.009

45. Siemann DN, Strange DP, Maharaj PN, Shi PY, Verma S. Zika virus infects human Sertoli cells and modulates the integrity of the in vitro blood-testis barrier model. J Virol 2017;91:1-45. https://doi.org/10.1128/JVI.00623-17

46. Hui L, Nie Y, Li S, et al. Matrix metalloproteinase 9 facilitates Zika virus invasion of the testis by modulating the integrity of the blood-testis barrier. PLoS Pathog 2020;16:e1008509. https://doi. org/10.1371/journal.ppat.1008509

47. Matusali G, Houzet L, Satie AP, et al. Zika virus infects human testicular tissue and germ cells. J Clin Invest 2018;128:4697-710. https://doi. org/10.1172/JCI121735

48. Musso D, Gubler DJ. Zika virus. Clin Microbiol Rev 2016;29:487-524. https://doi.org/10.1128/ CMR.00072-15

49. Foy BD, Kobylinski KC, Chilson Foy JL, et al. Probable non-vector-borne transmission of Zika virus, Colorado, USA. Emerg Infect Dis 2011;17: 880-2. https://doi.org/10.3201/eid1705.101939

50. Cassuto NG, Sifer C, Feldmann G, et al. A modified RT-PCR technique to screen for viral RNA in the semen of hepatitis $\mathrm{C}$ virus-positive men. Hum Reprod 2002;17:3153-6. https://doi.org/10.1093/ humrep/17.12.3153

51. Lorusso F, Palmisano M, Chironna $\mathrm{M}$, et al. Impact of chronic viral diseases on semen parameters. Andrologia 2010;42:121-6. https://doi. org/10.1111/j.1439-0272.2009.00970.x

52. Vicari E, Arcoria D, Di Mauro C, Noto R, Noto Z, La Vignera S. Sperm output in patients with primary infertility and hepatitis $\mathrm{B}$ or $\mathrm{C}$ virus; negative influence of HBV infection during concomitant varicocele. Minerva Med 2006;97:65-77.

53. Zhou XP, Hu XL, Zhu YM, Qu F, Sun SJ, Qian YL. Comparison of semen quality and outcome of assisted reproductive techniques in Chinese men with and without hepatitis B. Asian J Androl 2011;13:465-9. https://doi.org/10.1038/aja.2010.164 
54. Durazzo M, Premoli A, Di Bisceglie C, et al. Alterations of seminal and hormonal parameters: An extrahepatic manifestation of HCV infection? World J Gastroenterol 2006;12:3073-6. https://doi. org/10.3748/wjg.v12.i19.3073

55. Hofny ER, Ali ME, Taha EA, et al. Semen and hormonal parameters in men with chronic hepatitis C infection. Fertil Steril 2011;95:2557-9. https:// doi.org/10.1016/j.fertnstert.2011.05.014

56. La Vignera S, Condorelli RA, Vicari E, D'Agata R, Calogero AE. Sperm DNA damage in patients with chronic viral $\mathrm{C}$ hepatitis. Eur J Intern Med 2012;23:e19-24.https://doi.org/10.1016/j.ejim.2011. 08.011

57. Safarinejad MR, Kolahi AA, Iravani S. Evaluation of semen variables, sperm chromosomal abnormalities and reproductive endocrine profile in patients with chronic hepatitis C. BJU Int 2010;105:79-86. https://doi.org/10.1111/j.1464-410X.2009.08720.x

58. Wang X, Sharma RK, Gupta A, et al. Alterations in mitochondria membrane potential and oxidative stress in infertile men: A prospective observational study. Fertil Steril 2003; Suppl 2: 844-50. https://doi.org/10.1016/S0015-0282(03)00983-X

59. Kang X, Xie Q, Zhou X, et al. Effects of hepatitis $B$ virus $S$ protein exposure on sperm membrane integrity and functions. PLoS One 2012;7:e33471. https://doi.org/10.1371/journal.pone.0033471

60. Moretti E, Federico MG, Giannerini V, Collodel G. Sperm ultrastructure and meiotic segregation in a group of patients with chronic hepatitis B and C. Andrologia 2008; 40:286-91. https://doi. org/10.1111/j.1439-0272.2007.00818.X

61. Goldberg-Bittman L, Kitay-Cohen Y, Hadari R, Yukla M, Fejgin MD, Amiel A. Random aneuploidy in chronic hepatitis $\mathrm{C}$ patients. Cancer Genet Cytogenet 2008;180:20-3. https://doi. org/10.1016/j.cancergencyto.2007.09.009

62. WHO. Summary of probable SARS cases with onset of illness from 1 November 2002 to 31 July 2003 [Internet]. 2003. Available from: www.who. int (2003.7.31)

63. Li W, Moore MJ, Vasilieva N, et al. Angiotensin converting enzyme 2 is a functional receptor for the SARS coronavirus. Nature 2003;426:450-4. https://doi.org/10.1038/nature02145
64. Thomas GK, Dean E, Cynthia SG, et al. A novel coronavirus associated with severe acute respiratory syndrome. N Engl J Med 2003;348:1953-66. https://doi.org/10.1056/NEJMoa030781

65. Drosten $\mathrm{C}$, Günther $\mathrm{S}$, Preiser $\mathrm{W}$, et al. Identification of a novel coronavirus in patients with severe acute respiratory syndrome. N Engl J Med 2003;348:1967-76. https://doi.org/10.1056/ NEJMoa030747

66. Peiris JS, Lai ST, Poon LL, et al. Coronavirus as a possible cause of severe acute respiratory syndrome. Lancet 2003;361:1319-25. https://doi. org/10.1016/S0140-6736(03)13077-2

67. Marra MA, Jones SJ, Astell CR, et al. The genome sequence of the SARS-associated coronavirus. Science 2003;300:1399-404. https://doi. org/10.1126/science.1085953

68. Rota PA, Oberste MS, Monroe SS, et al. Characterization of a novel coronavirus associated with severe acute respiratory syndrome. Science 2003;300:1394-9. https://doi.org/10.1126/ science. 1085952

69. Ding Y, He L, Zhang Q, et al. Organ distribution of severe acute respiratory syndrome (SARS) associated coronavirus (SARS-CoV) in SARS patients: Implications for pathogenesis and virus transmission pathways. J Pathol 2004;203:622-30. https:// doi.org/10.1002/path.1560

70. Xu J, Qi L, Chi X, et al. Orchitis: A complication of severe acute respiratory syndrome (SARS). Biol Reprod 2006;74:410-16. https://doi.org/10.1095/ biolreprod.105.044776

71. Sergerie M, Mieusset R, Croute F, Daudin M, Bujan L. High risk of temporary alteration of semen parameters after recent acute febrile illness. Fertil Steril 2007;88:970.e1-7. https://doi. org/10.1016/j.fertnstert.2006.12.045

72. Evenson DP, Jost LK, Corzett M, Balhorn R. Characteristics of human sperm chromatin structure following an episode of influenza and high fever: A case study. J Androl 2000; 21: 739-46.

73. Devi BY, Sharma G, Polasa H. Induction of chromosomal aberrations in mice spermatocytes by unpurified and purified human influenza viruses. Indian J Med Res 1987;86:506-10. 
74. Thadani MA, Polasa H. Cytogenetic effects of inactivated influenza virus on male germ cells of mice. Hum Genet 1979;51:253-8. https://doi. org $/ 10.1007 /$ BF00283391

75. Sharma G, Polasa H. Cytogenetic effects of influenza virus infection on male germ cells of mice. Hum Genet 1978;45:179-87. https://doi. org/10.1007/BF00286960

76. Thadani MA, Polasa H. Cytogenetic effects of replicating and nonreplicating strains of influenza virus on male germ cells of mice. Hum Genet 1979;49:97103. https://doi.org/10.1007/BF00283391

77. Kochi AN, Tagliari AP, Forleo GB, Fassini GM, Tondo C. Cardiac and arrhythmic complications in Covid-19 patients. J Cardiovasc Electrophysiol 2020. https://doi.org/10.1111/jce.14479

78. Wong SH, Lui RN, Sung JJ. Covid-19 and the digestive system. J Gastroenterol Hepatol 2020; 35: 744-8.. https://doi.org/10.1111/jgh.15047

79. Meng $\mathrm{H}$, Xiong $\mathrm{R}$, $\mathrm{He} \mathrm{R}$, et al. C.T. imaging and clinical course of asymptomatic cases with COVID-19 pneumonia at admission in Wuhan, China. J Infect 2020. https://doi.org/10.1016/j. jinf.2020.04.004

80. Kim J, Thomsen T, Sell N, Goldsmith AJ. Abdominal and testicular pain: An atypical presentation of COVID-19. Am J Emerg Med 2020. https://doi.org/10.1016/j.ajem.2020.03.052

81. Pan F, Xiao XY, Guo JT, et al. No evidence of SARS-CoV-2 in semen of males recovering from COVID-19. 2020;113:1135-39. https://doi. org/10.1016/j.fertnstert.2020.04.024

82. Holtmann $\mathrm{N}$, Edimiris $\mathrm{P}$, Andree $\mathrm{M}$, et al. Assessment of SARS-CoV-2 in human semen-a cohort study. Fertil Steril 2020;114:233-8. https:// doi.org/10.1016/j.fertnstert.2020.05.028

83. Ma L, Xie W, Li D, et al. Effect of SARS-CoV-2 infection upon male gonadal function: A single center-based study. MedRxic 2020. https://doi. org/10.1101/2020.02.12.20022418

84. Rastrelli G, Di Stasi V, Inglese F, et al. Low testosterone levels predict clinical adverse outcomes in SARS-CoV-2 pneumonia patients. Andrology 2020. https://doi.org/10.1111/andr.12821

85. Schroeder M, Tuku B, Jarczak D, et al. The majority of male patients with COVID-19 present low testosterone levels on admission to intensive care in Hamburg, Germany: A retrospective cohort study. medRxiv 2020. https://doi. org/10.1101/2020.05.07.20073817

86. Li HW, Sui JH, Huang IC, et al. The S proteins of human coronavirus NL63 and severe acute respiratory syndrome coronavirus bind overlapping regions of ACE2. Virology 2007;367:367-74. https://doi.org/10.1016/j.virol.2007.04.035

87. He L, Ding Y, Zhang Q, et al. Expression of elevated levels of pro-inflammatory cytokines in SARS-CoV-infected ACE2+ cells in SARS patients: Relation to the acute lung injury and pathogenesis of SARS. J Pathol 2006;210:288-97. https://doi.org/10.1002/path.2067

88. Wu F, Zhao S, Yu B, et al. A new coronavirus associated with human respiratory disease in China. Nature 2020;579:265-9. https://doi.org/10.1038/ s41586-020-2008-3

89. Wrapp D, Wang NS, Corbett KS, et al. Cryo-EM structure of the 2019-nCoV spike in the prefusion conformation. Science 2020; 367(6483):1260-63. https://doi.org/10.1126/science.abb2507

90. Kuba K, Imai Y, Penninger JM. Multiple functions of angiotensin-converting enzyme 2 and its relevance in cardiovascular diseases. Circ J 2013;77: 301-8. https://doi.org/10.1253/circj.CJ-12-1544

91. Patel VB, Zhong JC, Grant MB, Oudit GY. Role of the $\mathrm{ACE} 2 /$ angiotensin 1-7 axis of the renin-angiotensin system in heart failure. Circ Res 2016;118:1313-26. https://doi.org/10.1161/CIRCRESAHA.116.307708

92. Turner AJ, Hiscox JA, Hooper NM. ACE2: From vasopeptidase to SARS virus receptor. Trends Pharmacol Sci 2004;25:291-4. https://doi. org/10.1016/j.tips.2004.04.001

93. Zhang H, Penninger JM, Li Y, Zhong N, Slutsky AS. Angiotensin-converting enzyme 2 (ACE2) as a SARS-CoV-2 receptor: Molecular mechanisms and potential therapeutic target. Intensive Care Med 2020;46(4):586-90. https:// doi.org/10.1007/s00134-020-05985-9

94. Verdecchia P, Cavallini C, Spanevello A, Angeli F. The pivotal link between ACE2 deficiency and SARS-CoV-2 infection. Eur J Intern Med 2020;76:14-20. https://oi.org/10.1016/j. ejim.2020.04.037 
95. Luttmer R, Dijkstra MG, Snijders PJF, et al. Presence of human papillomavirus in semen of healthy men is firmly associated with HPV infections of the penile epithelium. Fertil Steril 2015; 104(4):838-44. https://doi.org/10.1016/j.fertnstert. 2015.06.028

96. Rintala MA, Pollanen PP, Nikkanen VP, Grenman SE, Syrjanen SM. Human papillomavirus DNA is found in the vas deferens. J Infect Dis 2002;185(11):1664-7. https://doi. org/10.1086/340421

97. de Sanjose S, Diaz M, Castellsague X, et al. Worldwide prevalence and genotype distribution of cervical human papillomavirus DNA in women with normal cytology: A meta-analysis. Lancet Infect Dis 2007;7(7):453-9. https://10.1016/ S1473-3099-07-70158-5

98. Song C, Wang Y, Li W, et al. Absence of 2019 novel coronavirus in semen and testes of COVID-19 patients. Biol Reprod 2020. https://doi.org/10.1093/ biolre/ioaa050

99. Paoli D, Pallotti F, Colangelo S, et al. Study of SARS-CoV-2 in semen and urine samples of a volunteer with positive naso-pharyngeal swab. J Endocrinol Invest 2020; 23:1-4. https://doi. org/10.1007/s40618-020-01261-1

100. Ning J, Li W, Ruan Y, et al. Effects of 2019 novel coronavirus on male reproductive system: A retrospective study. Preprints 2020. https://doi. org/10.20944/preprints202004.0280.v1

101. Li DG, Jin ML, Bao PT, Zhao WG, Zhang SX. Clinical characteristics and results of semen tests among men with coronavirus disease 2019. JAMA Netw Open 2020;3(5):e208292. https://doi. org/10.1001/jamanetworkopen.2020.8292

102. Zhao S, Zhu W, Xue S, Han D. Testicular defense systems: Immune privilege and innate immunity. Cell Mol Immunol 2014;11:428-37. https://doi. org/10.1038/cmi.2014.38

103. Mruk DD, Cheng CY. The mammalian bloodtestis barrier: Its biology and regulation. Endocr Rev 2015;36:564-91. https://doi.org/10.1210/er. 2014-1101 